\title{
Peaceful atoms in agriculture and food: how the politics of the Cold War shaped agricultural research using isotopes and radiation in post war divided Germany
}

\section{Karin Zachmann (*)}

${ }^{*}$ ) orcid.org/0000-0001-5533-2211. Technische Universität München. Karin.Zachmann@tum.de

Dynamis

[0211-9536] 2015; 35 (2): 307-331

http://dx.doi.org/10.4321/S0211-95362015000200003
Fecha de recepción: 30 de junio de 2014

Fecha de aceptación: 7 de abril de 2015

SUMMARY: 1.- Introduction. 2.-Early research prior to the Cold War. 3.-Legal and material provisions: research as subject of allied power politics. 4.-West German research before 1955: resumptions of prewar efforts and new starts under allied control. 5.-The East German (re-) entry into nuclear research since 1955: Soviet assistance, new institutions and conflicting expectations. 6.-State fostered research in West Germany: launching the Atomic Research Program of the Federal Ministry of Agriculture. 7.-Conclusion.

ABSTRACT: During the Cold War, the super powers advanced nuclear literacy and access to nuclear resources and technology to a first-class power factor. Both national governments and international organizations developed nuclear programs in a variety of areas and promoted the development of nuclear applications in new environments. Research into the use of isotopes and radiation in agriculture, food production, and storage gained major importance as governments tried to promote the possibility of a peaceful use of atomic energy. This study is situated in divided Germany as the intersection of the competing socio-political systems and focuses on the period of the late 1940s and 1950s. It is argued that political interests and international power relations decisively shaped the development of «nuclear agriculture». The aim is to explore whether and how politicians in both parts of the divided country fostered the new field and exerted authority over the scientists. Finally, it examines the ways in which researchers adapted to the altered political conditions and expectations within the two political structures, by now fundamentally different.

KEY WORDS: nuclear agriculture, allied research assistance, application oriented research, Atomic Advisory Board for agricultural research, East German Commission for Isotope Research. 


\section{Introduction}

The Cold War boosted the application of atomic science in the area of agriculture and food since the 1950s on both sides of the Iron Curtain. The earliest research in this field can be traced back to as early as the close of the 19th century. Groundbreaking discoveries in nuclear physics and chemistry of the 1930s paved the way for more systematic work in that area. But only the most momentous wartime innovation - the atomic bomb itself - and the political context of the Cold War set the stage for a multiplied application of radioisotopes and ionizing radiation in agricultural research. The Cold War imbued all materials, practices and technologies in the field known since the late 1960s as «nuclear agriculture» with an intensely political significance ${ }^{1}$. This was so, because the Cold War super powers advanced nuclear literacy and access to nuclear resources and technology to the rank of a first-class power factor.

I argue here that political interests and international power relations decisively shaped the development of «nuclear agriculture», because they transformed the process of knowledge production in remarkable ways. Within the bipolar configuration of Cold War politics and with the advancement of science to a kind of competitive stage for the political blocs, the research agendas of scientific institutions became increasingly dependent on political requirements ${ }^{2}$. My investigation is situated in divided Germany, as the intersection of the competing socio-political systems, in particular, in the period between the late 1940s and 1950s, marked by the formation of the Iron Curtain and subsequent separation of research communities. Specifically, I will examine whether and how politicians exerted authority and influenced the mobilization of resources, people, materials, ideas and technology within the two fundamentally different political systems. Finally,

1. The term nuclear agriculture was introduced by the German physicist Hellmut Glubrecht and the Dutch biologist Dick de Zeeuw in 1969. In that year the two men initiated the European Society for Nuclear Agriculture (the website of the society is available at http:// web2.mendelu.cz/esna/, accessed November 27 2014). The aim was to foster research and development in this field that was ongoing since the mid-1950s. Nuclear agriculture made indirect reference to nuclear medicine as a successfully established and highly regarded field within medicine. Zachmann, Karin. Grenzenlose Machbarkeit und unbegrenzte Haltbarkeit? Das «friedliche Atom» im Dienst der Land- und Ernährungswirtschaft. Technikgeschichte. 2011; 78 (3): 231-253.

2. Greiner, Bernd; Müller, Tim; Weber, Claudia, eds. Macht und Geist im Kalten Krieg. Hamburg: Hamburger Edition; 2011. 
I will scrutinize how scientists adapted to the new situation in both parts of the divided country.

My investigation is based on published literature and on archival sources from the state archives in Koblenz and Berlin. For my depiction of West German development, I rely on minutes and letters from the Department of Agriculture to decipher the altered relationships between politics and science in the Cold War context of the late 1940s and 1950s. To understand the process of the politicization of science and its effects on the beginnings on «nuclear agriculture» in East Germany, I consulted sources from the Department of Agriculture and the Office for Nuclear Research and Engineering. Here, the minutes of the Commission for Isotope Research in the East German Academy of Agricultural Science contained the most revealing findings, because the commission worked as a contact zone between academic researchers, politicians and representatives of industry. Here, we are able to see how representatives of functionally differentiated societal sectors tried to impose or defend their sector specific rationales. The minutes of the Atomic Advisory Board of the Federal Department of Agriculture, which represent the West German counterpart of the East German Commission for Isotope Research, were not accessible; therefore a point-by-point comparison of the respective East and West German administrative bodies was impossible. Using sources originating primarily from state institutions, I focus on the interactions of international and national politics and science in the Cold War context, which enabled me to investigate the alteration of knowledge and technology transfers as part of Cold War politics. I herewith present a starting point for further research on the circulation of knowledge across the Iron Curtain, based on scientific journals and textbooks, as well as archives of scientific institutions in the field.

\section{Early research prior to the Cold War}

The application of radioactivity in biological and agricultural research began at the turn to the 20th century, developing out of scientific curiosity about the effects of ionizing radiation and radioisotopes on living organisms and their environments ${ }^{3}$. The discovery of radioactive material and ionizing

3. Jahn, Ilse; Lother, Rolf; Senglaub, Konrad et al. Geschichte der Biologie. Jena: VEB Gustav Fischer; 1982 (p. 472, 505); Rentetzi, Maria. Trafficking materials and gendered experimental practices. 
radiation, research on radioisotopes and the development of indicator and tracer technologies with isotopes represent key breakthroughs. The development of the particle accelerator in the early 1930s and the ability to generate radioisotopes and ionizing radiation opened the door for innovative research in technology, medicine, agriculture, industry and the natural sciences ${ }^{4}$.

In Germany, physicists (Hans-Joachim Born, Karl-Günther Zimmer, Boris Rajewski), chemists (Nikolaus Riehl, Konrad Lang) and biologists (Nikolaj Timoféev-Ressovsky, Hans Stubbe) at various Kaiser Wilhelm Institutes (KWI) collaborated with members of industry (Auergesellschaft) and other scientific institutions (e.g. Amt für physikalische Sonderfragen der Reichspost in Miersdorf, The Office for Special Questions related to Physics) to introduce nuclear technologies and develop new experimental systems in the area of the life sciences, offering new approaches to old questions and posing altogether new questions ${ }^{5}$. Plant geneticist Hans Stubbe worked on radiation-induced mutations for improving plants through mutation breeding. His research was most closely related to «nuclear agriculture» ${ }^{6}$. This initial phase of research on isotopes and radiation ended with the war and the collapse of the Nazi regime. The Allied occupation of Germany and its thorough dismantling of nuclear research, above all, in the Soviet

Radium research in early 20th century Vienna. New York: Columbia University Press; 2008 (p. 24-29). Available from: http://www.gutenberg-e.org/rentetzi/pdfs/rentetzi-chapter1.pdf [cited June 29 2014]; Zachmann, Karin. Risky rays for an improved food supply? Transnational food irradiation research as a Cold War recipe. Preprint Deutsches Museum. 2013; 7: 12.

4. Creager, Angela. Life atomic. A history of radioisotopes in science and medicine. Chicago: Chicago University Press; 2013 (p. 24-59); von Schwerin, Alexander. Prekäre Stoffe. Radiumökonomie, Risikoepisteme und die Etablierung der Radioindikatortechnik in der Zeit des Nationalsozialismus. N.T.M. 2009; 17 (1): 5-33.

5. Gausemeier, Bernd. Natürliche Ordnungen und Politische Allianzen. Biologische und Biochemische Forschung an Kaiser-Wilhelm-Instituten 1933-1945. Göttingen: Wallstein; 2005; Rheinberger, Hans-Jörg; Müller-Wille, Staffan. Vererbung. Geschichte und Kultur eines biologischen Konzepts. Frankfurt: Fischer Taschenbuch Verlag; 2009; Satzinger, Helga, Vogt, Annette. Elena Aleksandrovna und Nikolaj Vladimirovic Timoféeff-Ressovsky (1898-1973; 1900-1981). In: Jahn, Ilse; Schmitt, Michael, eds. Darwin \& Co. Eine Geschichte der Biologie in Portraits, Vol. II. München: C. H. Beck; 2001, p. 442-470; Stange, Thomas. Institut X. Die Anfänge der Kern- und Hochenergiephysik in der DDR. Stuttgart: Teubner; 2001, p. 32-35. As a source on biophysical research in Nazi Germany, Rajewski, Boris; Schön, Michael. Biophysics Part I and II. In: Office of Military Government for Germany Field Information Agencies Technical, ed. Fiat Review of German Science 1939-1946. Wiesbaden: Dietrichsche Verlagsbuchhandlung; 1948.

6. Gausemeier, n. 5, pp. 138-141. 
occupied zone and all sectors of Berlin -including the forced relocation of key scientific figures, such as Nikolaus Riehl, Klaus-Günther Zimmer, Nikolaj Timoféev-Ressovski and Hans-Joachim Born to the Soviet Unionbrought research on isotopes and radiation in Germany to a standstill?

\section{Legal and material provisions: research as subject of allied power politics}

Research prohibitions imposed by the Allies (Allied Control Council Law No. 25 of 29 April 1946 and the Allied High Commission Law No. 22 of 2 April 1950) forbade or impeded scientists who had remained in Germany from taking up their research after the war. Particle accelerators together with Geiger counters, mass spectrometers and mass spectrographs had been designated as «prohibited devices». Moreover, the Allies prohibited all access to both natural and artificial radioactive materials ${ }^{8}$. However, the law contained a proviso specifying that the Allied Security Agency was authorized to annul its prohibitions, which meant that research with radioisotopes and radiation began in some locations in West Germany in the late 1940s and early $1950 \mathrm{~s}^{9}$. Still, the proviso also meant research options were subject to the definitional power of the Allies. As we will see, the extent to which these options were restricted or permitted in divided Germany was intimately connected to the dynamics of the Cold War. The Allies officially lifted all research bans only when they vested sovereignty in the governments of West or East Germany respectively in 1955.

7. Wunderlich, Volker. Karl Günther Zimmer zum hundertsten Geburtstag: «That was the basic radiobiology that was». MDC 2011, p. 8. Available from: https://www.mdc-berlin.de/36243863/ de/about_the_mdc/history/biography/karlzimmer [cited June 29 2014].

8. Both laws are contained in Müller, Wolfgang D. Geschichte der Kernenergie in der Bundesrepublik Deutschland: Anfänge und Weichenstellungen. Stuttgart: Schäffer; 1990, p. 635-649.

9. Thus, Burghard Weiss had worked out that the French occupational forces organized the transfer of the KWI/MPI for Chemistry to Mainz in order to lend importance to the newly-founded university. In 1946 the existing parts of the Van de Graff Generator, in Berlin, were brought to Mainz and its restoration to operation was a part of the Institute's reopening in 1949. Weiss, Burghard. Groß, Teuer und gefährlich? Kernphysikalische Forschungstechnologien an Instituten der Kaiser-Wilhelm-Gesellschaft vor, während und nach dem Ende des «Dritten Reiches». In: Kaufmann, Doris, ed. Geschichte der Kaiser-Wilhelm-Gesellschaft im Nationalsozialismus. Bestandsaufnahmen und Perspektiven der Forschung. Göttingen: Wallstein; 2000, vol. 2, p. 699-725. 
One-by-one, first American, then British, Canadian and, finally, Soviet nuclear scientists were able to produce radioisotopes and radiation sources in greater variety as by-products of nuclear fission in atomic reactors, introducing new conditions for research on isotopes and radiation from a technical but, more importantly, political perspective. In short, radioisotopes became the elements of international politics ${ }^{10}$, serving, in effect, as indicators of political relations between producer and user states, but also, at least initially for the USA, as a means of surveillance of atomic research outside its national boundaries ${ }^{11}$. Yet in 1949, the Isotope Department of the Atomic Energy Research Establishment (AERE) in Harwell (UK) grew into the leading isotope exporter worldwide, supplying West Europe in particular, including West Germany, with short half-life radioisotopes. In 1951, the AERE in Harwell established an isotope school modeled after the one in Oak Ridge, Tennessee. Between 1951 and 1956, West German participants were the largest group of graduates from the isotope program ${ }^{12}$.

\section{West German research before 1955: resumptions of prewar efforts and new starts under allied control}

As the historical record shows, allied prohibitions on research in West Germany were only partially enforced, so that scientists and engineers in the Federal Republic gained access to materials and intellectual resources on radiation and isotope research markedly sooner than their colleagues in the East. At the Institute for Medical Research of the Max Planck Society, newly established in Göttingen in 1947, an isotope distribution agency was set up as early as 1949, with the permission of the occupying British authorities. This institute obtained radioisotopes from Harwell and, in

10. Creager, Angela. Radioisotopes as political instruments, 1946-1953. Dynamis. 2009; 29: 219-239; Creager, Angela; Santesmases, María Jesús. Radiobiology in the Atomic Age: Changing research practices and policies in comparative perspective. Journal of the History of Biology. 2006; 39 (4): 637-647; Santesmases, Maria Jesús. From prophylaxis to atomic cocktail: Circulation of radioiodine. Dynamis. 2009; 29: 337-363; Herran, Néstor. Isotope networks: training, sales and publications, 1946-1965. Dynamis. 2009; 29: 285-306; Krige, John. The politics of phosphorus-32: A cold war fable based on fact. Historical Studies in the Physical and Biological Sciences. 2005; 36 (1): 71-91.

11. Creager, n. 10, p. 230-231.

12. Herran, Néstor. Spreading Nucleonics: the Isotope School at the Atomic Energy Research Establishment, 1951-1967. British Journal of the History of Science. 2006; 39 (4): 569-586. 
turn, supplied other medical and research institutes in West Germany ${ }^{13}$. Training courses for working with isotopes were also carried out there ${ }^{14}$. But where and when were these radioactive materials being used? Germany's former KWI (now Max Planck Institutes, MPI) continued the work that had begun during the war at its new locations, though some of the key scientists involved in the application of nuclear methods in biology and the life sciences were still being held in the Soviet Union. According to the Institute's first activity report for 1951/52, experiments with radioisotopes and ionizing radiation were carried out at a number of locations. The MPI for Biochemistry in Tübingen recommenced work on the tobacco virus involving radioactive tracers ${ }^{15}$, while the MPI for Biophysics in Frankfurt am Main established a department for radioactive isotopes ${ }^{16}$.

In the fields of agronomy and nutritional science, a number of institutions, among them several universities, had begun working with radioisotopes and radiation sources before 1955. As early as 1951, the Institute for Animal Physiology at the University of Bonn began working with radioisotopes to examine sulfur metabolism in ruminant stomachs, as well as the sexual physiology of domestic animals using radioactive iodine. In 1953, the Agricultural Chemistry Institute of the Justus Liebig University in Giessen conducted studies on fertilizer intake using P-32, C-14 and Zn-65. The same

13. Jahrbuch der Max-Planck-Gesellschaft zur Förderung der Wissenschaften e.V. Part II. Göttingen; 1961, p. 567.

14. There was little experience in dealing with the material, to say nothing of the transport regulations or directives for radiation protection during transport and in the laboratory. The employees of the isotope distribution point reported great difficulties at airfields, in customs offices, and at tax offices. The receiving laboratories, on the other hand, had to learn that working quickly with isotopes with short lives was necessary so that the isotopes were not already decayed before use. Simultaneously, special transportation precautions had to be taken because the material gave off so much radiation in their shipping containers that the couriers were in immediate danger. See Jahrbuch der Max-Planck-Gesellschaft, n. 13, p. 567 and Letter Physikalisches Institut Bundesversuchs- und Forschungsanstalt für Milchwirtschaft Kiel to Bundesminister, 10.12.1955, p. 5. BA Koblenz, B116/15502.

15. Tätigkeitsbericht der Max-Planck-Gesellschaft zur Förderung der Wissenschaften für die Zeit vom 1.4.1951 bis 31.3.1952. Die Naturwissenschaften. 1952; 39: 463.

16. Tätigkeitsbericht 1951/52, n. 15, p. 464 and Tätigkeitsbericht der Max-Planck-Gesellschaft zur Förderung der Wissenschaften für die Zeit vom 1.4.1952 bis 31.3.1954. Die Naturwissenschaften. 1954; 41: 514. Experiments were underway there with P-32, I-131 and Au-198. Autoradiographic experimental methods were developed, and the isotope laboratory worked on problems of radiation protection when working with radioisotopes. Although the focus here was primarily on using isotopes in medicine, the results had general importance for setting up isotope laboratories. 
is true of the Agricultural Chemistry Institute of the University of Göttingen, though their studies were limited to P-32. In 1954, the Weihenstephan Agricultural Chemistry Institute began research on metabolic processes in various crops using radioactive nutrients ${ }^{17}$.

At the federal level, three institutes of the Ministry for Nutrition, Agriculture and Forests reported on work which had clearly begun before 1955. At the close of 1952, a radiation laboratory, equipped for work with ionizing radiation and radioisotopes, was set up at the Federal Research Center for Preservation of Fresh Foods in Karlsruhe, as reported by its director Johann Kuprianoff ${ }^{18}$. The goal was to develop food irradiation as an alternative conservation method (alternative to pasteurizing, sterilization, and chemical methods of sprout control) and to study the radioactive contamination of food, as well as potential protective measures. Beginning in 1953 (and possibly continuing until 1955), the Institute for Wood and Cellulose Chemistry at the Federal Research Center for Forestry and Wood Products employed C-14 and even Sr-90 to develop density measurements in wood for the quick determination of mass increase and to examine the biogenesis of various substances in living forest trees. Experiments were also conducted on the localization of uranium ore through uranium identification in wood ash and on the usability of radioactive waste from nuclear power plants as a wood preservative ${ }^{19}$. In 1955, the Institute for Grapevine Breeding Geilweilershof worked on the intake of nutrients and plant metabolism in various grape varieties using P-32 and C-14 ${ }^{20}$. The acquisition of radioisotopes was financed partially with contributions from the German Research Council (DFG) and partially with funds from the European Recovery Program. Ironically, funds provided by the Marshall Plan went into research projects which, according to Law 22 of the Allied

17. Berichte aus der land- und forstwirtschaftlichen Forschung, Presse- und Informationsdienst. In: Land- und Forstwirtschaftlichen Forschungsrat, ed. April 1957, Appendix: Isotopenforschung und Landwirtschaft. BA Koblenz, B116/15505.

18. Letter BA für Lebensmittelfrischhaltung to Bundesminister, 14.12.1955. BA Koblenz, B1 16/15502.

19. Letter BA für Forst- und Holzwirtschaft to Bundesminister, 8.12.1955. BA Koblenz, B116/15502. In addition, the institute reported attending training courses at «the Max Planck Society». It was also emphasized that a close relationship existed with the Atomic Research Center in Harwell for exchanging experiences.

20. Forschungsinstitut für Rebenzüchtung Geilweilerhof to Bundesminister, 12 December 1955. BA Koblenz, B116/15502. 
High Commission in Germany, were actually prohibited and only allowed with special authorization.

As a result of its integration into the socio-political system of western bloc countries, the Federal Republic of Germany (FRG) was provided access to materials, techniques and technology to perform isotope and radiation research in the areas of nutrition and agriculture even before gaining national sovereignty and before the lifting of prohibitions on nuclear science and technology. This enabled researchers like Boris Rajewski, who had developed the field of biophysics, and other scientists, who had started with the application of nuclear techniques in the biological and life sciences in the Berlin KWIs, to resume their research of the 1930s and early 1940s. Others, like Johann Kuprianoff, inspired by the high prestige of nuclear physics, began to use radioisotopes and radiation in their respective fields.

In 1955, however, the great research boom began, charged by the US's supply of research reactors to West Germany and the Soviet's to the East. The competitive dynamic of the Cold War set the pace for the development in nuclear research and technology, taking it in new directions. The ramifications of this dynamic on research and practice in the agriculture and food sector will be dealt with in the next section, starting with the eastern half of divided Germany.

\section{The East German (re-)entry into nuclear research since 1955: Soviet assistance, new institutions and conflicting expectations}

Researchers in the German Democratic Republic (GDR) only gained access to radioisotopes and radiation sources once the Soviet Union was prepared to provide the corresponding «assistance». An embargo made deliveries from the British nuclear research center in Harwell impossible until 1954, and the lack of foreign exchange kept them limited thereafter. From the very beginning, the British nuclear establishment had instituted an embargo against deliveries of radioisotopes to East Europe, arguing officially that radioisotopes provided for materials research could also be employed in the defense industry. In reality, however, it was the fear that contact with Soviet bloc states might adversely affect the already troubled British-American relationship regarding the nuclear sector, itself complicated by Cold War dynamics, which kept them from doing so. While the lifting of the radioisotope embargo in 1954, after Eisenhower's Atoms for Peace 
Initiative, may have presented an opportunity for East German scientists to re-enter the nuclear research community, British security concerns kept eastern Europeans out of its isotope courses until the isotope laboratory and school was moved to Wantage in $1959^{21}$. As a result, scientists in the GDR were forced to turn to the Soviet Union for material and intellectual support $^{22}$.

On 28 April 1955 (before the First Geneva Conference, at which the Eisenhower Administration announced its offer of a research reactor agreement) the USSR and the GDR signed an aid agreement, which included the delivery of a research reactor, the assembly of a cyclotron and the return of German nuclear specialists ${ }^{23}$. Efforts to retain scientists returning from the Soviet Union in the GDR by offering more attractive job opportunities forced government officials to establish material and institutional structures for nuclear research. One of the returning scientists, Hans-Joachim Born, was to head the Institute for Medicine and Biology in the East German Academy of Sciences established as a working area for applied isotope research in the Berlin quarter of Buch. In effect, Born found himself exactly where he had been a decade before as a member of the KWI research network ${ }^{24}$. Buch became the GDR's isotope distribution agency in 1958, for nearly half a decade coordinating the allocation of isotopes that were either imported from the USSR or generated in Rossendorf near Dresden ${ }^{25}$. Here, a nuclear research reactor, originating in the Soviet Union, was set up in $1957^{26}$.

By 1955, then, the GDR had access to radioisotopes. The Institute for Agricultural Chemistry at the Friedrich Schiller University in Jena,

21. Herran, n. 10, p. 578-582.

22. Thomas Stange reported on the preparations, beginning in 1949, for re-starting nuclear research. Stange, n. 5, p. 102-104.

23. Stange, n. 5, p. 105-109.

24. Stange, Thomas. Die Genese des Instituts für Hochenergiephysik der DAW zu Berlin (19401970) [doctoral thesis]. Hamburg; 1998, p. 66. Born left the GDR in 1957, after receiving his habilitation in radiochemistry and the application of radioactive isotopes at the Technical University Dresden. He was appointed director of the Institute of Radiochemistry at the Technical University Munich in 1957. Petschel, Dorit. Die Professoren der TU Dresden, 18282003. Köln: Böhlau Verlag; 2003, p. 118-119.

25. Radiochemist Günther Vormum was director of the isotope distribution point. BA Berlin, DF1/1411.

26. Reichert, Mike. Kernenergiewirtschaft in der DDR. St. Katharinen: Scripta Mercaturae Verlag; 1999, p. 145-153. In the very same year also the first West German research reactor from the US was erected in Garching near Munich. 
headed by plant physiologist Gerhard Michael, was the first agricultural institute to begin work with tracer technology. In May 1955, Moscow sent its first shipment of radioactive phosphorus for the institute's study of phosphate fertilizer intake and use in plants ${ }^{27}$. With the scientific and technical support of the physical and technical institutes of the university in Jena, where the GDR set up its first particle accelerator in 1956, Michael established the first isotope laboratory for agricultural research in the GDR at his institute ${ }^{28}$.

From 1956 to 1960 Michael acted as chairman of the Commission for Isotope Research in the (Ost)-Deutschen Landwirtschaftsakademie [(East) German Academy of Agricultural Sciences (GAAS) ${ }^{29}$. This commission was to foster and coordinate research in the application of isotopes and ionizing radiation in the area of agriculture and food. Politicians initiated the founding of the commission. Willy Stoph, then acting chair of the GDR Council of Ministers, announced in a letter to Agriculture Minister Reichelt dated 5 March 1956 that there would be radioisotope imports from the Soviet Union and requested that the minister investigate potential fields of application and the resulting need for the machinery, equipment and facilities ${ }^{30}$. The addressee for the suggestions was the Amt für Kernforschung und Kerntechnik [Office for Nuclear Research and Engineering (ONRE)], which, as a counterpart to the Ministry of Atomic Affairs in the FRG, coordinated research and investment in the new fields in the GDR ${ }^{31}$. The agriculture minister delegated the task to the GAAS. Here, the chair of the section Soil Science, Plant Nutrition, and Cultivation, Dr. Schlegel, took up the task of compiling a list of relevant research projects, and the necessary equipment, in all sections of the academy. On 29 March 1956, Schlegel, who would later become secretary of the Isotope Commission, submitted a summary of projects and required equipment to the ONRE ${ }^{32}$. In some of these projects, the researchers referred to West German work

27. Michael, Gerhard; Machold, Otto; Wilberg, E. Über Untersuchungen mit radioaktivem Phosphor auf dem Gebiet der Pflanzenernährung. Wiss. Z. Friedrich-Schiller-Universität Jena, Math.Naturwiss. Reihe. 1955/56; 5: 69-74.

28. It was a betatron with a capacity of 17 MeV. Stange, n. 24, p. 124.

29. Meeting minutes of the Commission for Isotope Research. BA Berlin, DF1/1087.

30. Letter Stoph to Reichelt, 5.3.1956. BA Berlin, DK1/1323/16.

31. On the department of nuclear research and technology, see Reichert, n. 26, pp. 121-125.

32. Letter Schlegel to Amt für Kernforschung und Kerntechnik 29.3.1956. BA Berlin, DK1/1323/22-26. 
and even, in the area of food irradiation, to technical facilities in the USA, which demonstrates that they were well informed about the latest research in the West (figure 1).

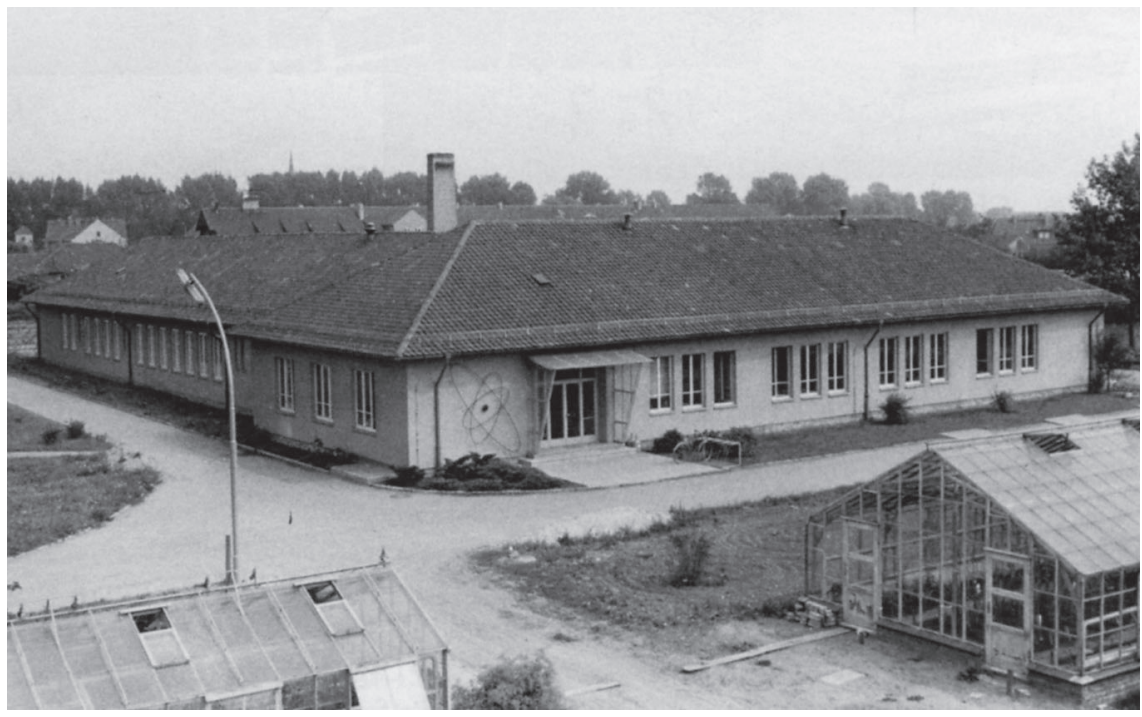

Figure 1: Isotope laboratory of the institute for research on cultivated plants of the East German Academy of Agricultural Science, Gatersleben. Please note the stylized atom at the left side of the entrance. Source: Müntz, Klaus; Wobus, Ulrich. Das Institut Gatersleben und seine Geschichte. Berlin: Springer; 2013, S.52. Used with permission.

Beginning in May 1956, the Isotope Commission convened meetings two or three times a year. Participants included researchers of the GAAS and the universities, officials from the Agriculture Ministry, the ONRE and the Staatliche Plankommission [the State Planning Commission $(\mathrm{SPC})]$, and, later, representatives from industry. Then president of the Academy of Agricultural Sciences, Hans Stubbe, who, as member of the research network of the Berlin KWIs, had already worked with isotopes on radiation-induced mutation breeding, occasionally took part in the Isotope Commission meetings. The meetings always began with a lecture on a special topic and reports on new research projects, followed by travel and conference reports, practical questions regarding equipment engineering, 
training opportunities and other issues ${ }^{33}$. The meeting's minutes give an impression of the development of new working areas and of a steadily more intensive examination of Soviet research. They also reflect the very tense relationship between the scientists and the planning and science policy of the leading party SED, which pressured researchers to produce concrete research results and to quickly apply them to agricultural practice. The scientists expressed reservations about the SED's high expectations. In so doing, they even cited critical statements from Soviet researchers to give their arguments more weight. At the second meeting, Commission Chairman Michael warned against euphoric exaggerations regarding progress in the new fields, referring to limits, error sources and possible errors in the application of isotope methods ${ }^{34}$. At the fourth commission meeting, Otto Machold of the university in Jena cited his Soviet colleague Professor Achromeiko, who had complained at the Moscow isotope convention in April 1957 that isotope research was being conducted on problems already explicated some 30 years ago ${ }^{35}$.

Practical application was the highest goal of isotope and radiation research in the Soviet Union, as well as in the USA ${ }^{36}$. Fast and effective results served each nation's interest in positioning itself as the more technologically advanced within the ideological struggle between the political systems. The East German Isotope Commission received reports of Soviet attempts to increase crop yields by irradiating seeds, soaking seeds in radioactive solutions, or introducing radioactive nutrients during plant development. These projects, however, were controversial even within the Soviet Union. Scientists of the GAAS's Isotope Commission considered these experiments

33. Session minutes of the Commission for Isotope Research and report on the work of the Isotope Commission from May 1956 to December 1959. BA Berlin, DF1/1087.

34. Minute of the session 7 December 1956. BA Berlin, DF1/1087.

35. Minute of the session 15 July 1957. BA Berlin, DF1/1087.

36. On US plant breeding research with radioisotopes and ionized rays, Curry, Helen. Accelerating Evolution. Engineering Life. American Agriculture and Technologies of Genetic Modification, 1925-1960. Yale: [unpublished PhD]; 2012; on food irradiation research in the USA, Buchanan, Nicholas. The Atomic Meal. The Cold War and Irradiated Foods, 1945-1963. History and Technology. 2005; 21 (2): 221-249; Hastings, Diane E. Factors Associated with the Emergence and Acceptance of Food Irradiation in the United States. Columbia University; [doctoral thesis] 1995; Spiller, James. Radiant cuisine. The commercial fate of food irradiation in the United States. Technology \& Culture. 2004; 45 (4): 740-763; Zachmann, n. 3, p. 13-16. 
wholly useless, because of the resultant radioactive contamination of soil and crops $^{37}$.

At the close of 1958, political pressure within the GDR increased pushing scientists to develop practical, technological applications for radioisotopes. The Second United Nations Atoms for Peace Conference in Lake Geneva in September 1958 provided the impetus, making clear that expectations of a quick turn to nuclear power had to be lowered ${ }^{38}$. Instead, isotope and radiation research received proportionately significant attention - some 11 volumes of the 32 volume publication of the conference proceedings are devoted to isotope and radiation research and applications, with volume 27 exclusively covering «Radioisotopes in Agriculture» ${ }^{39}$. On 4 December 1958, the SPC of the GDR reached a «resolution to intensify the use of radioactive isotopes in industry», at the core of which was the call to draw up a plan for the use of radioisotopes and radiation technology for the period until $1965^{40}$. In a session two months later, the SPC extended the resolution to include applications in the agricultural sector ${ }^{41}$.

Functionaries on the Planning Commission specified their requirements in the spring of 1960, criticizing the plan put before them for including fundamental research only. They demanded

«[...] a healthy percentage of research devoted to such economically relevant issues as insect and pest control, limiting losses of crops in storage, or the enhancement and acceleration of serial tests, such as techniques for analyzing the nitrogen, phosphorous and potassium content of soil $[\ldots] \gg{ }^{42}$.

The plan, it was maintained, also lacked an adequate review and analysis of contemporary research and techniques for radioactive as well as stable isotope applications as conducted internationally in both the Soviet Union and in the West. While Soviet research involving the irradiation of seeds

\footnotetext{
37. 4th session 15 July 1957 and 7th session 26 June 1958. BA Berlin, DF1/1087.

38. Hampe, Eckhard. Zur Geschichte der Kerntechnik in der DDR von 1955 bis 1962. Die Politik der Staatspartei zur Nutzung der Kernenergie. Dresden: HAl; 1996, p. 47; Radkau, Joachim. Aufstieg und Krise der deutschen Atomwirtschaft. Reinbek: Rowohlt; 1983, p. 89-90

39. Proceedings of the second United Nations international conference of the peaceful uses of atomic energy. Vol. 27: Isotopes in Agriculture. Geneva: United Nations; 1958.

40. Excerpts from the resolution of the SPC on 4 Dec. 1958. BA Berlin, DK1/6904/248-250.

41. Deliberation of the SPC 20 Feb. 1959, BA Berlin, DF1/1097 part 1.

42. Contribution to the counsel of Isotope Commission representatives on 25 May 1960. BA Berlin, DK1/6904/171-177.
} 
and plants was, in fact, controversial, the critique contended, evidence of its success in increasing yields warranted greater attention, as did the application of radioisotopes for the preservation of crops during storage ${ }^{43}$. The Commission referred directly to the work reports of the OEEC project number 396 of the European Productivity Agency published in 1958 and 1959, which provided an overview of research activities devoted to the application of nuclear science in agriculture and the food industry in the USA and western Europe ${ }^{44}$. The Commission also closely monitored the activities of the International Atomic Energy Agency in Vienna ${ }^{45}$. The IAEA's emphasis from the very beginning on the development of nuclear technologies for agriculture strengthened the determination of Commission planners in the GDR to expand their nuclear research and technology beyond industry and medicine to include agriculture, as well ${ }^{46}$.

The call for the international orientation of research planning points to the grave disadvantage of the position of GDR scientists, whose colleagues in the West, as a result of the western integration of the FRG in the second half of the 1950s, had been involved in transnational research and technology networks and international institutions that, in many cases, had been instigated by the USA ${ }^{47}$. East German researchers had no access to it, and their attempts to combat this isolation from the scientific community through the intensification of cooperative research within eastern Europe

43. Driven by the desire to win the next Cold War battle in the field of science and engineering after the successful launch of Sputnik, the USSR became the first country in the world to approve the sale of irradiated potatoes in March 1958. A year later this authorization was followed by the approval of the irradiation of grain to eliminate insect infestation. Canada cleared irradiated potatoes for human consumption in 1960. Diehl, Johannes. Safety of irradiated foods. 2nd ed. New York: CRC Press; 1995, p. 342, 348.

44. European Productivity Agency, ed. Applications of Atomic Science in Agriculture and Food: Report of Mission to the United States sponsored by the European Productivity Agency under Project No. 396, Paris: OEEC; 1958; European Productivity Agency, ed. Applications of Atomic Science in Agriculture and Food: Present Positions, Future Trends and Techniques. Report of the Working Conference, held at the Headquarters, Paris, July 1958, Project no. 396. Paris: OEEC; 1959.

45. The GDR was not eligible to become a member of the IAEA until it entered the UNO in 1973, while the FRG had representatives in the IAEA from the start, some of whom had even held positions within the organization since the 1960s.

46. On IAEA's activities in the field of agriculture and food, Hamblin, Jacob Darwin. Let there be light ... and bread: The United Nations, the developing world, and atomic energy's green revolution. History and Technology. 2009; 25 (1): 22-48; Zachmann, n. 3, p. 34-38, and the article of Hamblin in this issue.

47. Zachmann, n. 3, p. 38-40. 
were dependent upon the willingness of the Soviet Union to develop such networks within the Soviet sphere of power ${ }^{48}$. It was not until 1960 that the Council for Mutual Economic Assistance (COMECON) set up the Standing Commission for the Peaceful Uses of the Atom, providing a framework to institutionalize networks of interaction and collaboration among scientists in the East ${ }^{49}$. Consequently, the flow of knowledge during the 1950s and early 1960s adapted to the bipolar pattern of Cold War political culture. While this bipolar structure might be considered permeable, insofar as scientists on both sides of the Iron Curtain carefully monitored their colleagues across the divide, still publishing in the same journals and quoting one another's publications, such remote knowledge of colleagues' activities can never replace the benefits of immediate and direct collaboration.

GDR scientists made use of their knowledge of international research in struggles over policy at home. The dispute concerning research priorities culminated in sessions of the Isotope Commission in 1960. At the 11th session of the Isotope Commission, Kurt Unger of the Institute for Plant Breeding in Quedlinburg raised the issue of the application of ionizing radiation and neutrons for measurement techniques, in particular, the measurement of soil moisture with radioactive sources. Unger stressed that recourse should be taken to radioactive sources only when all other techniques had failed, citing evidence from a comparative study of moisture measurement techniques conducted in the USA in which isotope measurement received the lowest marks. Isotope application, he warned, should not become an end in itself ${ }^{50}$.

In a subsequent discussion concerning the seven-year research plan, one functionary on the Planning Commission insisted that the devotion of scientific research to practical concerns should lead to a better balance between «fundamental and application-oriented research», pointing by example to the potential benefits of research on the irradiation of potato

\footnotetext{
48. Zachmann, Karin. Ambassadors of the New Ostpolitik? How ESNA and preceding actors shaped and challenged the Cold War order. Paper at the Conference «Dark matters-contents and discontents of Cold War science» 30.5.-2.6.2013, University of Barcelona.

49. Uhlig, K. 10 Jahre Ständige Kommission des RGW für die friedliche Anwendung der Atomenergie. Isotopenpraxis Isotopes in Environmental and Health Studies. 1971; 7 (2): 37-42; Uschakow, Alexander. Integration im RGW. Baden-Baden: Nomos Verlagsgesellschaft; 1983, p. 140-144.

50. 11th session on 3 June 1960. BA Berlin, DF1/1087.
} 
beetles as a pest control measure ${ }^{51}$. Scientists at the session, however, protested that such applications were feasible only within the scope of a laboratory but fully inappropriate when transferred to the natural world in all its immensity. Radioisotope techniques, they felt, were in this respect wholly overestimated. After all, they contended, the research results of the Soviet scientist Professor Kletschowski had shown that such applications did not lead to direct increases in crop yields. In fact, this session of the Isotope Commission would be the last for Commission Chair, Gerhard Michael. Soon thereafter Michael left the GDR for the West and accepted a call to chair the Department of Plant Nutrition and Soil Biology at the Agricultural University in Hohenheim near Stuttgart in the same year ${ }^{52}$.

Still, the 11th session did not end disastrously. The chair of the Department of Food Chemistry at Humboldt University in Berlin, Josef Herrmann, and a member of the Planning Commission reported on the status of research involving food irradiation and announced the start of large-scale projects with potatoes. In fact, the irradiation of potatoes and other vegetables would come to be the focus of research activities whose results were to be «speedily put into practice», as the Minister of Agriculture demanded ${ }^{53}$.

The next session of the Isotope Commission on 21 September 1960 discussed the Planning Commission's call for a research plan to focus on the application of radioisotopes in agricultural research and the development of practical techniques ${ }^{54}$. Three fields of radioisotope application to be fasttracked for agricultural practice had already been laid out by the Minister of Agriculture: 1. sprout control for potatoes in storage, 2. the irradiation of fresh vegetables intended for storage to extend shelf life, and 3. testing and evaluation processes in agricultural engineering. Two working groups with representatives from all areas affected by the measure were set up for implementing the innovations in an organized manner.

51. During the early Cold War, the potato beetle was suspected of being implemented by the enemy as a biological weapon. Kellerhoff, Sven; Keil, Felix; Broder, Lars. Gerüchte machen Geschichte. Folgenreiche Falschmeldungen im 20. Jahrhundert. Berlin: Ch. Links Verlag; 2013, p. 135-158.

52. Marschner, Horst. Professor Dr. Dr. h. c. Gerhard Michael zum 70. Geburtstag. Zeitschrift für Pflanzenernährung und Bodenkunde. 1981; 144 (1): i-ii.

53. 11th session on 3 June 1960. BA Berlin, DF1/1087.

54. 12th session on 21 Sept. 1960. BA Berlin, DF1/1087. 
The not yet confirmed projects, however, suggested by the Ministry, met with harsh criticism in this round of discussion. Scientists pointed out the Minister's lack of knowledge and outright errors on two points, remarking with agitation that «irradiation with stable isotopes as proposed in the draft plan was simply not possible» ${ }^{55}$. Another proposed project was judged by scientists to be outright nonsense, as «the problem of fat deposition cannot be solved using activated N-15, because fat does not contain nitrogen ${ }^{56}$. Two further projects were rejected as entirely irrelevant in the face of already extant and far more effective conventional techniques, while the four additional areas of proposed application research first required basic research before the question of application could even be broached. In the end, less than half of the projects in the Ministry's draft plan were accepted without criticism.

The reaction of the scientists to the Ministry's plans, however, should by no means be construed as a general rejection of the use of nuclear technology in agriculture and food science. Isotope and radiation techniques were introduced across the spectrum in this field after 1955, with at least seven institutes at various academies and universities performing research with radioisotopes by $1959^{57}$. The pressure exerted on scientists by policies demanding the rapid applicability of their research was the main source of conflict between scientists and functionaries. De facto, the scientists' resistance was, at the same time, resistance to their exploitation in the ideological battles of the Cold War. This cannot be said of all GDR scientists, however, as the case of Prof. Herrmann, mentioned above, illustrated. He saw policy makers' plans as an opportunity to establish his reputation in the field of food irradiation. The GDR, however, only began employing the practice on a grand scale after Herrmann's retirement in the early 1980s. But that is another story. Let us return, now, to the year 1955 and take a look at developments on the other side of the Iron Curtain.

55. Protocol of the 12th session of the Isotope Commission on 21 Sept. 1960. BA Berlin, DK1/6904/116.

56. Protocol, n. 55, p. 117.

57. Schlegel to Rost, 16 Dec. 1959. BA Berlin, DF1/1087. 


\section{State fostered research in West Germany: launching the Atomic Research Program of the Federal Ministry of Agriculture}

The year 1955 marks a significant turning point in nuclear research and technology in the FRG. Following the early isotope research and experiments with ionizing radiation depicted above, which were authorized by the Allies even before prohibitions against nuclear research had been lifted, the reinstatement of national sovereignty brought with it an expansion of the possibilities for nuclear research. In 1955 the Ministry of Atomic Affairs was established under the direction of Franz Josef Strauß. It clearly signaled the importance of the Republic's rapid inclusion in the atomic age to the chancellor Konrad Adenauer. Even before the Cabinet approved his proposal in a session on 6 October $1955^{58}$, exploratory talks were already underway within existing ministries about the question of «atomic research». In a Ministry of Agriculture meeting on 14 September 1955 ${ }^{59}$, the decision was reached to invite Johann Kuprianoff, Director of the Federal Research Institute for Food Preservation in Karlsruhe, and Wolfgang Flaig, Director of the Institute for Soil Biochemistry at the Institute for Agricultural Research in Braunschweig-Völkenrode, to serve as atomic advisors to the Federal Ministry for Nutrition, Agriculture and Forestry (FMA) ${ }^{60}$. While Kuprianoff had already begun researching in the field, Flaig had signaled interest in radioisotope research in the summer of $1955^{61}$. On 30 September 1955, Flaig compiled a list of radioisotope research projects planned at his institute in Braunschweig ${ }^{62}$ (figure 2).

58. 99th Cabinet meeting on 6 Oct. 1955. In: Die Kabinettsprotokolle der Bundesregierung online. Available from: http://www.bundesarchiv.de/cocoon/barch/011/k/k1955k/kap1_2/kap2_46/ para3_8.html [cited May 13 2014].

59. Memorandum 20 Sept. 1955. BA Koblenz, B116/15502.

60. Kuprianoff had been negotiating with the FMA since February 1955 to receive funding for the construction of a nuclear bunker to conduct experiments with ionizing radiation. On 25 May 1955, he wrote a letter giving weight to his request, arguing that Karlsruhe could become the central institute for atomic research if the MPI for physics and a reactor were at his facility and the Federal Research Institute for Food Preservation the central site of food irradiation research only if its infrastructure and scope were expanded and developed. Kuprianoff to the FMA, 25 May 1955. BA Koblenz, B116/15502. Shortly thereafter Karlsruhe was chosen as the site for the second reactor.

61. Memorandum of the FMA from 28 June 1955. BA Koblenz, B116/15502.

62. Braunschweig, 30 Sept. 1955, Zentrale Einrichtung für die Arbeit mit Isotopen an der Forschungsanstalt für LW. BA Koblenz, B116/15502. 


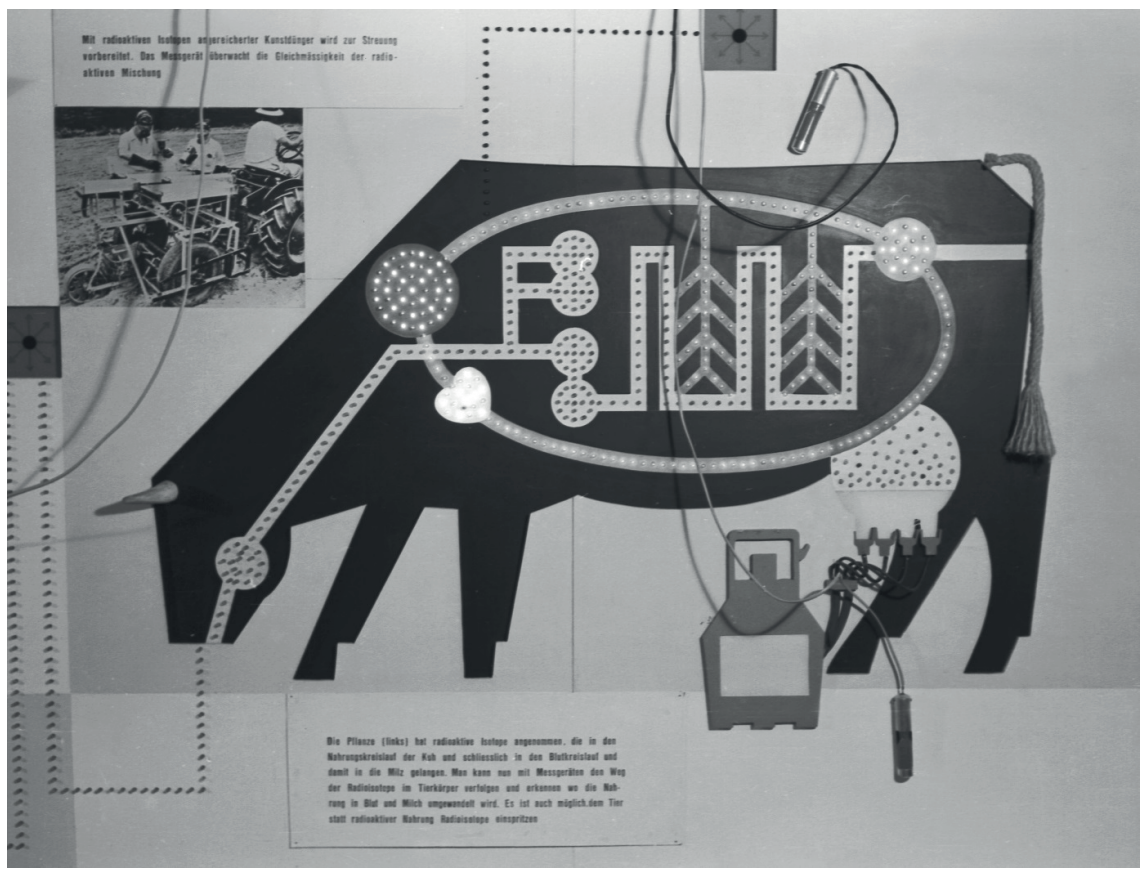

Figure 2: Display board on research with radioisotopes in agriculture at the atom exhibition at Deutsches Museum Munich from 17.10. to 7.11.1955. Source: Deutsches Museum, Archiv, Museumsgeschichte Leica 0001-3049. Bildstellennummer: *L1918-15, used with permission.

On 15 November 1955, a session of the FMA took place in which both Kuprianoff and Flaig took part ${ }^{63}$. The first item on the agenda was to clarify the meaning and parameters of nuclear research as encompassing work with radioisotopes as well as with ionizing radiation sources ( $\mathrm{x}$-rays, gamma and beta radiation). Another priority established in the session was to take stock of the work already being carried out in the field of «atomic research». To this end, a questionnaire was developed under the supervision of Kuprianoff and Flaig and sent to the various research institutes within the Republic. Among other information to be gathered for the Ministry, the survey sought to establish the equipment and construction requirements for expanded atomic research in order to plan and requisition adequate financial 
resources. Those institutes working with radioisotopes and radiation, it was determined, must also be adequately instructed about safety requirements and measures, for which Kuprianoff had already drawn up a set of guidelines. Finally, members of the session voted to establish an advisory board within the FMA devoted to the concerns of nuclear science.

The Atomic Advisory Board, established on 27 November 1955, was the West German counterpart to the GDR's Isotope Commission. Its members consisted of the directors of the various research institutes interested in isotope and radiation research - virtually all of them wereand representatives of the Ministry of Agriculture ${ }^{64}$. By the close of 1955, most of the research institutes had submitted their responses to the FMA survey. In February of the new year, the Ministry compiled a list of topics in «atomic research under the auspices of the FMA», subdivided into the categories «peaceful» and «military» applications ${ }^{65}$. The rubric of «peaceful applications» was divided between the agricultural and the nutrition sector. Atomic research in agriculture was devoted to the areas of plant and animal nutrition, plant breeding, plant disease and pest control, and the prevention of epidemic disease in animal populations. Atomic research in the nutrition sector included the following four areas:

«a) the preservation of food through electron irradiation (gamma rays ${ }^{66}$ ) to eradicate bacterial pathogens and delay the decomposition process,

b) the analysis of radioactively-treated foods regarding their nutritional suitability for human consumption,

c) the monitoring of imported foodstuff and feeding stuff suspected of radioactive contamination before their processing and handling or sale to consumers,

d) the monitoring of fish, caught in catch zones suspected of radioactive contamination, for their level of radioactivity» ${ }^{67}$.

\footnotetext{
64. Memorandum from 27 Nov 1955. BA Koblenz, B116/32398.

65. Carbon copy, Min. Rat Dr. Tornow, 25.2.1956. BA Koblenz, B116/15502.

66. Gamma rays are not produced through electron acceleration. The erroneous formulation here is likely derived from lack of knowledge on the part of the ministry administrator who authored the text.

67. Carbon copy, n. 65. Further research using radioactive cobalt for the preservation of butter, meat and fish, as well as fat hardening was announced, for which the Federal Research Institute for Dairy Farming in Kiel, for fat research in Münster and for meat processing in Kulmbach had expressed interest.
} 
The last two points are a direct response to the new threat posed by nuclear testing, which had become a central issue of public debate following the radioactive contamination of the Japanese fishing boat «Lucky Dragon» as a result of the USA's nuclear tests in $1954^{68}$. Under the rubric of «military applications», the Ministry included «the development of safety and decontamination measures, in particular, those concerning the decontamination of soil, cultivated plants, livestock, and agricultural infrastructure, food and feeding stuffs and storage facilities» ${ }^{6}$. In other words, measures to be undertaken in the wake of a nuclear attack.

The Ministry, then, compiled its list of research priorities in full awareness of the double-edged nature of radioactivity. Its destructive potential was a factor of which Kuprianoff, in particular, was keenly aware. His correspondence with the Ministry continually stressed both the benefits of research on the irradiation of foodstuff for the improvement of conservation, sterilization, etc. and the use of such research for the «worstcase scenario». At that time, the US was leading the way in preparing «for the worst». Since 1953, the US Army had been conducting comprehensive research on food irradiation under the direction of the US Quartermaster Corps $^{70}$. The Army's interest in this research stemmed from the scenario of food provision to troops and civilian populations in the context of a nuclear war, which would only be possible with radiosterilized foods. Irradiated food, then, was exhalted as a safety measure against radioactive contamination in nuclear war. In the wake of the NATO Council's decision in May 1957, that all future wars were to be planned as nuclear wars, the issue of national food conservation and storage became a central element of contingency planning, making the irradiation of foodstuffs a key issue of national security. That is precisely what the West German Ministry of Agriculture did in October 1957 in an urgent confidential communication to the Ministry of Finance validating the pressing need for additional funding for the development and expansion of the radiation division of the Federal

68. On the emerging fallout crisis and its global dimension, Higuchi, Toshihiro. Radioactive fallout, the politics of risk, and the making of a global environmental crisis, 1954-1963. Washington DC: Georgetown University [doctoral thesis PhD]; 2011. Available from: https://repository. library.georgetown.edu/bitstream/handle/10822/558065/Higuchi_georgetown_0076D_11445. pdf?sequence=1, p. 72-136 [cited 29 June 2014].

69. Carbon copy, n. 65

70. Zachmann, n. 3, p. 14-16. 
Research Institute for Food Preservation ${ }^{71}$. Kuprianoff's research enjoyed, thereafter, generous financial support and the FRG became a leader in research on food irradiation - but not, however, in its practical application ${ }^{72}$.

Atomic research in the agricultural sector in West Germany experienced rapid growth with the boost in financial resources in the wake of regaining national sovereignty in 1955. The Ministry of Agriculture's atomic research program laid out in August 1957 encompassed projects in eleven federal research institutes, with the institute in Braunschweig-Völkenode becoming the central site for research in agriculture and Karlsruhe for research in nutrition ${ }^{73}$. Isotope research in the field of agriculture conducted at institutions of higher education in 1957 was taking place at ten different institutes at seven universities ${ }^{74}$. Projects for the construction of isotope laboratories were undertaken at universities and colleges in Hohenheim, Weihenstephan (with the supply of isotopes coming from the research reactor in Garching), Göttingen and Kiel ${ }^{75}$. Radioisotope and radiation research at the biological and agricultural institutes of the Max Planck Society also underwent further expansion.

\section{Conclusion}

Scientists in both halves of divided Germany were able to pick up the thread of research on radioisotopes and radiation in the fields of biology, agriculture and the life sciences, which took place before and during WWII primarily within the context of the KWI. Scientists in the West were able to conduct this research markedly earlier than their colleagues in the East, as a result of Allied authorization as early as 1949 loosening prohibitions against nuclear research. Moreover, equipment and facilities for testing, as

71. Urgent memorandum, 30 Oct. 1957. BA Koblenz, B116/32398. In its decision on 23 May 1957, NATO stated that any future general wars must be planned as nuclear wars. Final decision on Mc 48/2. A Report by the Military Committee on Measures to implement the strategic concept, 23 May 1957. Available from: http://www.nato.int/docu/stratdoc/eng/a570523b.pdf [cited 5 Feb 2013].

72. Zachmann, Karin. Atoms for peace and radiation for safety - How to build trust in irradiated foods in Cold War Europe and beyond. History and Technology. 2011; 27 (1): $65-90$ (82).

73. The atomic research program of the Federal Ministry for Nutrition, Agriculture and Forestry, 31 August 1957. BA Koblenz, B116/15502.

74. Berichte, n. 17.

75. Berichte, n. 17. 
well as radioisotopes themselves, were made available to western scientists. In the GDR, by contrast, radioisotopes for research in agriculture were first made available by the Soviet Union in 1955, though work had already begun on the development of the necessary technologies.

The institutional structures for atomic and nuclear research established in both East and West Germany beginning in the second half of the 1950s were quite similar: the West German Ministry for Atomic Affairs found its counterpart in the GDR's Office of Nuclear Research and Technology. The Ministry of Agriculture in both countries coordinated atomic research in this field. In the FRG, the Ministry of Agriculture engaged its federal research institutes for this purpose, selecting two -Karlsruhe and BraunschweigVölkerode - to head research activities. In the GDR, representatives of the Ministry of Agriculture had selected the newly founded Academy of Agricultural Science to head the effort. The Atomic Advisory Board was the West German counterpart to the GDR's Isotope Commission.

In both German states, nuclear research in the agricultural sector was financed and coordinated exclusively at the federal level. In the GDR, policy makers also sought to play a central role in defining the objectives of scientific research, which many scientists resisted. These conflicts culminated in a confrontation on the proper relationship between basic and applied research. In the FRG, by contrast, scientists themselves took the lead in establishing the practical relevance of their research in the interest of mobilizing financial resources, as seen, for example, in the efforts of Johann Kuprianoff to persuade the ministries of agriculture and finance of the merits of his research through references to its significance in the event of nuclear war. In public discourse, Kuprianoff stressed instead its benefits to the civilian population and the significance of food irradiation within the overall context of the development of nuclear technology.

The cross-border transfer of knowledge and application techniques using radioisotopes and radiation in agriculture followed the bipolar pattern of ideological confrontation driven by both superpowers. The development of two antagonistic power blocs divided the scientific community in Germany, integrating them into different networks of knowledge. While scientific communication, nevertheless, continued across the Iron Curtain, it became limited to the circulation of explicit, i.e. clearly stated and verbalized knowledge in the form of publications. Without direct collaboration and human interaction, however, tacit knowledge, experience and know-how could not travel across the Iron Curtain. The importance of the latter forms 
of knowledge, however, increased markedly in the early stages of nuclear applications in agriculture and food. The resultant transnational research and technology networks and institutions of direct collaboration remained largely confined within the borders of the antagonistic political blocs in the 1950s and early 1960s. Only the emergent climate of détente, beginning in the mid 1960s, gradually began to open lines of communication for all forms of knowledge. 